\title{
REVIEW
}

\section{DRUG TRIALS FOR TREATMENT OF HUMAN ANGIOSTRONGYLIASIS}

\author{
Márcia Bohrer MENTZ(1) \& Carlos GRAEFF-TEIXEIRA(2)
}

\begin{abstract}
SUMMARY
Abdominal and cerebral angiostrongyliasis are two important infections produced by metastrongylid worms, the former occurring in Central and South America and the later in Asia and Pacific Islands. Drug treatment is a challenge since the worms and its evolving larvae live or migrate inside vessels and efficient killing of the parasites may produce more severe lesions. Larvicidal effect of certain drugs appears to be more easily accomplished but this outcome is not useful in abdominal angiostrongyliasis since clinical manifestations appear to result from sexual maturation of the worms. We review the drug trials in murine experimental models and conclude that most of them could not be considered good candidates for treatment of human infection, except for PF1022A, pyrantel and flubendazole.
\end{abstract}

KEYWORDS: Eosinophilia; Angiostrongyliasis; Tissue-dwelling parasites; Anthelmintic drugs; Zoonosis.

\section{INTRODUCTION}

Human angiostrongyliasis has been widely reported from various parts of the world. Among the food-borne zoonotic diseases, Angiostrongylus cantonensis ${ }^{4}$, the causative agent of human eosinophilic meningoencephalitis ${ }^{1}$, and Angiostrongylus costaricensi $^{32}$, the causative agent of human abdominal angiostrongyliasis have such a medical importance that studies have been carried out in order to search for suitable drugs. The trials of treatment have been done both on adults and larvae stages.

It is known that drug efficacy is influenced by various factors including route, dosage and regimen of the treatment. In addition, in the treatment of diseases produced by tissue-dwelling parasites, allergenic components of killed worms may cause adverse effects on the host ${ }^{7,8,17}$. Therefore, effective treatment will be established after these factors are taken into account through basic studies using experimental models.

\section{CHEMOTHERAPY AFTER WORM MATURATION}

Many studies have examined the effects of various neuropharmacological agonists and antagonists on the motility of nemathelmints, suggesting the existence of excitatory cholinergic and inhibitory gabergic mechanisms.

Avermectin B1a, one of the parasitic macrocyclic lactones produced by actinomycets of Streptomyces avermitilis, may act on the nervous system of various nematodes as well as other animals including crustacea and mammals, possibly through an effect on $\gamma$-amino-butyric acid (GABA). It was also suggested that it could paralyze Angiostrongylus cantonensis, through a neuropharmacological mechanism including GABA and acetylcholine ${ }^{24,35}$.

SANO et al..$^{36}$ developed an in vitro method to study the effects of drugs on the motility of small helminths and observed the paralyzing effects of avermectin B1a on Angiostrongylus cantonensis, using $3^{-6} \mathrm{X}$ $10^{-18} \mathrm{mg}$. The drug caused a sustained inhibition in the motility, with a relaxation of the parasite. ISHII et al. ${ }^{13}$ extended the in vitro studies to in vivo experiments in rats. Avermectin B1a was given intraperitoneally (ip) six weeks after infection, and a sustained paralysis of worm by this drug was suggested from the following aspects: the change of the first larval stage count in feces; histological observations of lung tissues of the host and the reproductive system of female worms, and the motility of recovered worms in vitro. When the drug was given per os (po), three days after infection, a significant reduction in the recovery rate of worms was observed.

ISHII et al. ${ }^{14}$ administered ivermectin ip to rats infected with Angiostrongylus cantonensis. They observed a significant reduction in the recovery of adult worms when the drug was given at $2 \mathrm{mg} / \mathrm{kg} 0.5$ to $72 \mathrm{~h}$ and four weeks after infection, compared to the non-treated, infected control group.

TERADA et al. ${ }^{49,50}$ searched the effects of some alkaloids on the motility of some parasitic helminths, isolated frog rectus and mouse ileum. They verified that tuberostomine (TS) at $6.7 \times 10^{(-6)}$ approximately

(1) Instituto de Ciências Básicas da Saúde, Depto. de Microbiologia, Setor de Parasitologia, UFRGS

(2) Faculdade de Biociências e Instituto de Pesquisas Biomédicas, PUCRS.

Correspondence to: Márcia Bohrer Mentz, Rua Sarmento Leite 500, 90050-170 Porto Alegre, RS, Brasil. Email: mbmentz@uol.com.br 
$2 \times 10^{(-5)}$, an alkaloid from Stemona japonica, abolished the motility of A. cantonensis. With N-methylcystisine (N-MC) and matrine (Mat), alkaloids from Sophora flavescens, the motility of A. cantonensis musculature was affected spastically by $\mathrm{N}-\mathrm{Mc}\left(1.2 \times 10^{-6}\right.$, approximately $1.2 \times 10^{-4} \mathrm{M}$ ), and paralytically by Mat $10^{(-5)}$, approximately $10^{(-4)} \mathrm{M}$. From the results on interactions between these alkaloids and known neuropharmacological agents, it was suggested that the effects of both alkaloids are elicited through a neuropharmacological mechanism in parasitic helminths and host tissues.

TERADA et al $^{40}$ examined the effects of various cholinergic agents on the motility of $A$. cantonensis to define their neuropharmacological properties. It was suggested that the excitatory cholinergic mechanism in this parasite was mediated through nicotinic receptors, and it was basically similar to that reported in Ascaris suum. The same group demonstrated spastic paralysis caused by pyrantel tartrate, another gabergic anthelmintic, through direct stimulation of the nicotinic cholinergic receptors in A. cantonensis ${ }^{41}$.

TERADA et al. ${ }^{42}$ compared the paralysis of $A$. cantonensis produced by avermectin B1a and ivermectin to that produced by phenylephrine (an alpha-adrenergic agonist) and strychnine (a cholinergic inhibitor) and concluded that a gabergic mechanism is involved in the paralyzing action of both macrocyclic lactones.

The reproductive functions of $A$. cantonensis are apparently affected by milbemycin $\mathrm{D}$, another macrocyclic lactone derivate, through an indirect mode of action including paralysis and inhibition in food intake and energy and/or synthetic metabolism ${ }^{38}$. The in vitro motility of females recovered from rats was inhibited, and almost all females and males were semitransparent colourless. Results obtained from sectioned worms showed little content in the digestive tract and uteri. In addition, there were few eggs and first-stage larvae in the lung tissues of treated rats. Inhibitory and stimulatory actions of milbemycin oxime on the motility of A. cantonensis and Dirofilaria immitis are probably mediated through gabergic and cholinergic mechanisms ${ }^{26}$. TERADA \& $\mathrm{SANO}^{46}$ studied the effects of santonin on the motility of A. cantonensis and some other parasitic nematodes. Santonin paralyzed the worms at lower concentrations $\left(10^{-9}-10^{-7} \mathrm{M}\right)$, whereas a slight stimulatory effect on the motility was also seen at its higher concentrations $\left(10^{-6}-10^{-4} \mathrm{M}\right)$. The results suggested that santonin has inhibitory and stimulatory actions through stimulating gabergic and cholinergic mechanism in the parasite.

CUCKLER et al. ${ }^{5}$ conducted studies to determine whether thiabendazole, a potent and broad-spectrum anthelmintic, would affect Angiostrongylus cantonensis. They showed that this drug was highly effective in controlling the early invasive stages of the rat lungworm. Also depending upon the dosage, time, and duration of medication, the worms were killed, their migration to the lungs was delayed and the oviposition was prevented.

MORERA \& BONTEMPO ${ }^{33}$ tested diethylcarbamazine (DEC), thiabendazole and albendazole as treatment of cotton rats (Sigmodon hispidus) infected with $A$. costaricensis, 40 days after infection. Several trials were carried out, varying the dose and the timing of the treatment. They demonstrated that the parasites were actively moving instead of being killed and also that lesions were more severe after treatment.
TERADA \& $\mathrm{SANO}^{47}$ examined the effects of diethylcarbamazine (DEC) on the motility of adult A. cantonensis and Dirofilaria immitis. They suggested that the DEC inhibitory and stimulatory action was produced through the gabergic and cholinergic mechanisms in both adult parasites. Other neuropharmacological agents, including eserine, phenyllephrine and dibenamine, did not have any effect on the motility of irradiated and non-irradiated Angiostrongylus cantonensis adult females ${ }^{15}$.

TERADA et al..$^{45}$ compared in vitro effects of 19 anthelmintics on the motility of $A$. costaricensis and A. cantonensis. Phenolic compounds (hexylresorcinol, bithionol and niclosamide) and levamisole were all effective on the motility of $A$. costaricensis, but other derivates having piperazine (diethylcarbamazine and piperazine), lactone (santonin, avermectin B1a and ivermectin) and benzimidazole (mebendazole and thiabendazole) had no efficacy at all.

TERADA et al. ${ }^{51}$ did some preliminary trials on treatment after worm maturation in abdominal angiostrongyliasis in mice, using mebendazole, one of the effective antilarval drugs against nematodes, including $A$. costaricensis. No definitive conclusion about killing efficacy was made and several topics were suggested to be addressed in forthcoming studies, like the influence of immune status of the host on the efficacy of the drug.

Mebendazole at $10 \mathrm{mg} / \mathrm{kg}$ nd with four intermittent doses of $5 \mathrm{mg} /$ $\mathrm{kg}$ given weekly led to a lowest worm recovery of A.costaricensis, in groups treated with four daily successive doses, suggesting involvement of different killing mechanisms. Otherwise, since the drug is not highly effective to kill the worms, the inhibition of egg formation and/or oviposition would be more desirable for treating abdominal angiostrongyliasis after worm maturation ${ }^{54}$.

KACHI et al. ${ }^{18}$ examined the effects of PF1022A, a cyclodepsipeptide isolated from a mycelial cake of Mycelia sterilia, on adult Angiostrongylus cantonensis in the pulmonary arteries and larvae migrating into the central nervous systems of rats, although the compound does not pass the bloodbrain barrier. The treatment killed especially female worms. This gender selective effect would be attributable to non-neuropharmacological mechanisms ${ }^{20}$.

\section{CHEMOTHERAPY BEFORE WORM MATURATION}

Considering the migration paths of developing larvae of Angiostrongylus cantonensis in vertebrates and the probable association of worm maturation and pathogenic changes caused by Angiostrongylus costaricensis, it is important to test the efficacy of drugs on the early stages of infection, with both nematodes.

HAYASHI et al. ${ }^{9}$ examined the effects of mebendazole against $A$. cantonensis in rats. The drug was more effective in the larval stage $\left(3^{\text {rd }}\right.$ and $4^{\text {th }}$ stages) than in the adult stage. Reduction rates higher than $90 \%$ were observed in groups treated with $\geq 3 \mathrm{mg} / \mathrm{kg}$, that was similar to its clinical dosis (3 -10 mg/kg) for human intestinal nematodes. When mebendazole suspended in propylene glycol was given orally or intraperitoneally, no difference in reduction rate was seen between two routes.

MAKI \& YANAGISAWA ${ }^{28}$ compared the effects of flubendazole and thiabendazole on the larvae of Angiostrongylus cantonensis and other helminths. Thiabendazole had no larvicidal effect on A. cantonensis at 
the doses of $10 \mathrm{mg} / \mathrm{kg} /$ day for six consecutive days. On the other hand, no larvae were found in the brain of the mice treated with flubendazole at $5 \mathrm{mg} / \mathrm{kg} /$ day for six days. The same high efficacy of flubendazole $(50$ $\mathrm{mg} / \mathrm{kg}$ po) was seen in mice with different worm burdens $(50,250$ or 500 larvae of $A$. cantonensis) with almost complete larvicidal effect, irrespective of the worm burden. The results also suggested that worm density had an effect on the fecundity of this parasite ${ }^{29}$. This effect may be due to fibrous changes in host lung tissues and not to changes in the physiology of the worms. The density-dependent effects on fecundity play a role in the population dynamics of both the parasite and host as regulatory mechanisms in the field.

MAKI \& YANAGISAWA ${ }^{30}$ gave flubendazole and mebendazole po at $10 \mathrm{mg} / \mathrm{kg} /$ day $5-7$ days post-infection (total $30 \mathrm{mg} / \mathrm{kg}$ ), resulting in 93-100\% reduction of $A$. cantonensis larvae in mice and rats. No significant difference was observed between the effects of the two drugs. It was possible to treat $A$. cantonensis adults in rats by administering flubendazole or mebendazole at $10 \mathrm{mg} / \mathrm{kg} /$ day for 10 consecutive days. The drugs exhibit better anthelmintic efficacy in a divided than in a single dosis regimen.

ISHIH et al. ${ }^{16}$ obtained significant inhibition on egg development of Angiostrongylus costaricensis in vitro caused by pyrantel $\left(10^{(-9)}-10^{(-80)}\right.$ $\mathrm{g} / \mathrm{ml}$ ) and levamisole $\left(10^{(-9)}-10^{(-8)} \mathrm{g} / \mathrm{ml}\right)$. None of the eggs developed to first-stage larvae in higher concentrations of these anthelmintics $\left(10^{(-7)} \mathrm{g} / \mathrm{ml}\right)$. Furthermore, incubation with these drugs at $10^{(-8)} \mathrm{g} / \mathrm{ml}$ for at least $3 \mathrm{~h}$ or at $10^{(-4)} \mathrm{g} / \mathrm{ml}$ for $1 \mathrm{~h}$ caused irreversible effects on egg development.

MAKI \& YANAGISAWA ${ }^{31}$ determined the effect of flubendazole po administered at $10 \mathrm{mg} / \mathrm{kg} /$ day for five consecutive days (the $11^{\text {th }} ; 20^{\text {th }}$ or $40^{\text {th }}$ post-infection) on the number of first-stage larvae of Angiostrongylus cantonensis, released in the faeces of rats. Faecal examination for five months showed that L1 release ceased one week after conclusion of treatment and resumed one to two months later in $86 \%$ of the rats.

In order to study the sensitivity of the developing larvae and adult of A. cantonensis, flubendazole and mebendazole were administered at 10 $\mathrm{mg} / \mathrm{kg}$ to rats 3 and 10 days post-infection and to those harbouring the adult worms after 70 days post-infection. Almost all of the larvae were eliminated from the rats medicated 3 days post-infection. The larvicidal effects of the drugs administered 10 days post-infection were not so high. On the other hand, when the drugs were administered 70 days post-infection, no effects were seen on the number, body size and weight of recovered worm and the release of L1, concluding that the developing larvae were more sensitive to the drugs ${ }^{27}$.

KANDA \& $\mathrm{MAKI}^{23}$ observed the in vitro egg release of $A$. cantonensis from rats treated with flubendazole and demonstrated that the drug, even at the single dose as low as $10 \mathrm{mg} / \mathrm{kg}$, affected the physiology of adult worms in rats. No direct evidence was obtained on effects of flubendazole po administered to rats on eggs and the firststage larvae. The authors hypothesized that flubendazole might affect the formation of fertilized eggs from early embrionated stages and/or the release of the eggs from the worms immediately after the conclusion of the treatment, leading to the reduction in the number of the L1. Testing these hypothesis is worthy of further investigations.
KAMATH et al. ${ }^{22}$ observed the larvicidal effect of perbendazole given po and subcutaneously to mice infected with $A$. cantonensis at different stages of infection. The subcutaneous route of administration was more effective than the oral one. They also showed the complete larvicidal effect of the drug at early stages of infection.

KAMATH et $a l .{ }^{21}$ verified that the combined therapy of levamisole and flubendazole was $100 \%$ efficient against $A$. cantonensis infection in mice. The drugs were evaluated on the $15^{\text {th }}$ day post infection. Both drugs given prior to experimental infection showed no prophylactic activity.

The larvicidal effect of albendazole was studied in the experimental infection with Angiostrongylus cantonensis in mice treated with dosages of 5,10 and $25 \mathrm{mg} / \mathrm{kg} /$ day beginning 5,10 or 15 days post-infection, respectively, for 7,14 or 21 consecutive days. It was effective when given within 15 days post-infection ${ }^{10}$.

Levamisole was another anthelmintic tested against larval stages of A. cantonensis in rats and A. costaricensis in mice and the results suggested that the drug had conspicuous in vivo effects against larval stages of $A$. costaricensis as well as $A$. cantonensis ${ }^{12}$. ISHII ${ }^{11}$ also verified the effects of levamisole on the first-stage larva of A. cantonensis and suggested that levamisole affected the L1 output through a direct paralyzing action on the worm and an indirect pathway through inhibition of energy metabolism.

ISHII et al. ${ }^{14}$ administered ivermectin intraperitonially to rats infected with Angiostrongylus cantonensis. When the drug was given at $2.0 \mathrm{mg} / \mathrm{kg}$ after 3 weeks post infection, a significant inhibition of the first larval stage output in rat faeces was observed.

TERADA et al..$^{39}$ examined the anti-larval effects of milbemycin D on A. cantonensis in rats and mice and on A. costaricensis in mice. Compared with non-treated control group, significant reductions in the first stage larval counts in feces (LPG/female), number of recovered worms, host lung-body weight ratio, body weight, and mortality were seen in the groups receiving 10 successive daily doses of $5 \mathrm{mg} / \mathrm{kg}$, both in rats and mice. Some effect was also seen with five or 20 successive doses. From these results, it was suggested that milbemicyn D had conspicuous in vivo effects against larval stages in both nematodes.

PF1022A killed developing larvae of A. costaricensis after five successive doses and it was well absorbed either po or by parenteral administration ${ }^{43}$. This larvicidal activity was observed with any of the four forms of PF1022A, although forms alpha and III were more efficient against tissue-dwelling nematodes than the form I and form II when given $\mathrm{po}^{20}$.

\section{CHEMOTHERAPY AND IMMUNE STATUS OF THE HOST}

Great interest has been recently directed towards advances in understanding the interactions between chemotherapeutic actions of antiparasitic drugs and immune status of the host. Most of the studies using such approach have been carried out on anti-protozoan and anti-trematode chemotherapy.

Immunosuppression may reduce the efficacy of treatment in experimental hosts infected with several parasitosis, including 
schistosomiasis, malaria, trypanosomiasis, filariasis ${ }^{6}$ and strongyloidiasis ${ }^{37}$. The enhancement of drug efficacy through immunopotentiation was also demonstrated for some diseases caused also by tissue parasites like schistosomiasis ${ }^{25}$ and visceral leishmaniasis ${ }^{2}$. However, individual variability of the host's immune response prevents a clear control for demonstration of the drug effects.

The fungal metabolite cyclosporin A (CsA) has been used as a tool of investigating cellular immune mechanisms in various parasitic infections $\mathrm{s}^{52}$. YOSHIMURA et al. ${ }^{55}$ tried to determine the possible effects of cyclosporin A (CsA) on Angiostrongylus cantonensis infection and eosinophilia in mice. The data indicated a direct damaging activity of CsA against certain developmental stages of the parasite.

TERADA \& $\mathrm{SANO}^{48}$ did trials to assess protective resistance against reinfection with Angiostrongylus costaricensis in mice whose primary infection was treated with milbemycin $\mathrm{D}$, a larvicidal anthelmintic. The protection was more remarkable in three situations: 1 ) when the larvicidal treatment was done later; 2) with high inocula at the primary infection; $3)$ when the infection and larvicidal treatment was repeated. The protective resistance lasted at least six months after primary infection.

TUNGTRONGCHITR et al. ${ }^{53}$ investigated the relation between immunopotentiation and efficacy of mebendazole in sensitized mice infected with adult $A$. costaricensis. A significant decrease in the establishment of infection and in worm growth was probably the result of development of a protective humoral immunity in the sensitized mice.

\section{CONCLUSION}

Although the many experimental studies on drug treatment of Angiostrongylus sp. infections in mice and rats, many aspects are still open to investigation before studies on human infection are carried out. Several compounds have a significant larvicidal effect, what may be specially useful in treating cerebral angiostrongyliasis. Otherwise, in abdominal angiostrongyliasis, the most striking clinical manifestations occur after worm maturation and there is also the concern about the possibility of extended lesions secondary to parasite's death inside blood vessels. Longitudinal seroepidemiological studies are urgently required to further clarify the natural history of human infection in both cerebral and abdominal angiostrongyliasis. This knowledge is critical for future phase II and III studies with candidate drugs.

\section{RESUMO}

\section{Ensaios com drogas para o tratamento da angiostrongilíase humana}

Angiostrongilíase abdominal e cerebral são duas infecções importantes produzidas por metastrongilídeos, a primeira delas ocorrendo nas Américas Central e do Sul e a segunda, na Ásia e Ilhas do Pacífico. O tratamento é complicado pelo fato das larvas e vermes adultos viverem e migrarem dentro dos vasos sanguíneos, sendo que as lesões podem se agravar com a morte desses parasitos. Os efeitos larvicidas de determinadas drogas parecem ser mais eficazes, porém não são úteis no tratamento em angiostrongilíase abdominal, onde as manifestações clínicas podem resultar da maturidade sexual dos vermes. Este estudo faz uma revisão das drogas utilizadas para o tratamento de ambas as parasitoses, em modelos experimentais murinos, realizados antes e depois da maturação dos vermes. A maioria das drogas testadas não pode ainda ser considerada candidata a ensaios de tratamento em infecções humanas, com exceção do PF1022A, pirantel e flubendazol.

\section{REFERENCES}

1. ALICATA, J.E. - Angiostrongylus cantonensis (Nematoda: Metastrongylidae) as a causative agent of eosinophilic meningitis of man in Hawaii and Tahiti. Canad. J. Zool., 40: 5, 1962

2. BADARO, R.; FALCOFF, F.; BADARÓ, F.S. et al. - Treatment of visceral leishmaniasis with pentavalent antimony and interferon gamma. New Engl. J. Med., 322: 16-21, 1990.

3. CÉSPEDES, R.; SALAS, J.; MEKBEL, S. et al. - Granulomas entéricos y linfáticos con intensa eosinofilia tisular producidos por un strongilídeo (strongylata). Acta méd. costarric., 10: 235-255, 1967.

4. CHEN, H.T. - Un nouveau nematode pulmonaire, Pulmonema cantonensis n.g.n. sp. des rats de Canton. Ann. Parasit. hum. comp., 13: 312-317, 1935.

5. CUCKLER, A.C.; EGERTON, J.R. \& ALICATA, J.E. - Therapeutic effect of thiabendazole on Angiostrongylus cantonensis infection in rats. J. Parasit., 51: 392-396, 1964.

6. DOENHOFF, M.J.J.; MODHA, J.R.; LAMBERTUCCI, J.R. \& MCLAREN, D.J. - The immune dependence of chemotherapy. Parasit. today, 7: 16-18, 1991.

7. HAWKING, F. - Diethylcarbamazine and new compounds for the treatment of filariasis. Adv. Pharmacol., 16: 129-194, 1979.

8. HAYASHI, M. - Studies on chemotherapy of parasitic helminths. (XXX). Clinical and pathological changes in mice infected with Angiostrongylus cantonensis and treatment with mebendazole and betamethasone. Jap. J. Parasit., 36: 80-87, 1987.

9. HAYASHI, M; TERADA, M.; ISHII, A; KINO, H. \& SANO, M. - Studies on chemotherapy of parasitic helminths. (XVI). Anthelmintic effect of Mebendazole on Angiostrongylus cantonensis in rats. Jap. J. Parasit., 31: 575-580, 1982.

10. HWANG, K.P. \& CHEN, E.R. - Larvicidal effect of albendazole against Angiostrongylus cantonensis in mice. Amer. J. trop. Med. Hyg., 39: 191-195, 1988.

11. ISHII, A. - Effect of the anthelmintic levamisole on the first-stage of Angiostrongylus cantonensis in infected rats. Parasit. Res., 80: 267-270, 1994.

12. ISHII, A.I.; TERADA, M.; FUJIU, Y. \& SANO, M. - In vivo efficacy of levamisole against larval stages of Angiostrongylus cantonensis and Angiostrongylus costaricensis. Southeast Asian J. trop. Med. publ. Hlth., 20: 109-117, 1989.

13. ISHII, A.I.; TERADA, M.; KINO, H.; HAYASHI, M. \& SANO, M. - Studies on chemotherapy of parasitic helminths: effects of avermectin B1a on Angiostrongylus cantonensis in rats. Int. J. Parasit., 13: 491-498, 1983.

14. ISHII, A.I.; TERADA, M. \& SANO, M. - Studies on chemotherapy of parasitic helminths. (XXIII). Effects of ivermectin on Angiostrongylus cantonensis in rats. Jap. J. Parasit., 34: 411-417, 1985.

15. ISHII, A.I.; TERADA, M. \& SANO, M. - Motility and drug susceptibility of Angiostrongylus cantonensis developing from gamma-irradiated first-stage larvae. Southeast Asian J. trop. Med. publ. Hlth., 18: 547-551, 1987.

16. ISHIH, A.; YANOH, M.; IKEYA, C.; BAN, A. \& TERADA, M. - Effects of anthelmintics on the development of eggs of Angiostrongylus costaricensis in vitro. J. Helminth., 75: 351-354, 2001

17. JOUBERT, J.; JOUBERT, M.J. \& LOMBAARD, C.M. - Neurocysticercosis: a comprehensive approach to medical treatment. S. Afr. med. J., 68: 11-14, 1985. 
18. KACHI, S.; ISHIH, A. \& TERADA, M. - Effects of PF1022A on adult Angiostrongylus cantonensis in the pulmonary arteries and larvae migrating into the central nervous system of rats. Parasit. Res., 81: 631-637, 1995.

19. KACHI, S.; TERADA, M. \& HASHIMOTO, H. - Influence of PF1022A on the motility of Angiostrongylus cantonensis in vitro. Parasit. Res., 83: 578-582, 1997.

20. KACHI, S.; TERADA, M. \& HASHIMOTO, H. - Effects of amorphous and polymorphs of PF1022A, a new antinematode drug, on Angiostrongylus costaricensis in mice. Jap. J. Pharmacol., 77: 235-245, 1998.

21. KAMATH, V.R.; MENON, S.; BHOPALE, M.K.; DESHPANDE, V.R. \& RENAPURKAR, D.M. - Experimental chemotherapy of Angiostrongylus cantonensis infection in mice with flubendazole, levamisole and their combination. Folia Parasit. (Praha), 34: 87-92, 1987.

22. KAMATH, V.R.; MENON, S. \& RENAPURKAR, D.M. - Larvicidal effect of perbendazole on experimental infection of Angiostrongylus cantonensis in mice. Chemotherapy, 33: 445-447, 1987

23. KANDA, S. \& MAKI, J. - In vitro observation on egg release by Angiostrongylus cantonensis from rats treated with flubendazole. Kitasato Arch. exp. Med., 65: $155-158,1992$

24. KASS, I.S.; WANG, C.C.; WALROND, J.P. \& STRETTON, A.O. - Avermectin B1a paralyzing anthelmintic that affects interneurons and inhibitory motoneurons in Ascaris. Proc. nat. Acad. Sci. (Wash.), 77: 6211-6215, 1980.

25. LAMBERTUCCI, J.R.; MODHA, J.; CURTIS, R. \& DOENHOFF, M. - The association of steroids and schistosomicides in the treatment of experimental schistosomiasis. Trans. roy. Soc. trop. Med. Hyg., 83: 354-357, 1989.

26. LEE, H.H. \& TERADA, M. - In vitro effects of milbemycin oxime: mechanism of action against Angiostrongylus cantonensis and Dirofilaria immitis. Parasit. Res., 78: 349353,1992

27. MAKI, J. \& KANDA, S. - Higher sensitivity of the developing larvae of Angiostrongylus cantonensis than the adult worms to flubendazole and mebendazole. Kitasato Arch exp. Med., 65: 131-136, 1992.

28. MAKI, J. \& YANAGISAWA, T. - A comparison of the effects of flubendazole and thiabendazole on the larvae of Angiostrongylus cantonensis, Trichinella spirallis, Diphyllobothrium erinacei and Hymenolepis nana in mice. Parasitology, 87: 525531, 1983.

29. MAKI, J. \& YANAGISAWA, T. - Larvicidal effect of flubendazole on Angiostrongylus cantonensis in mice with various worm burdens. J. Helminth., 59: 301-302, 1985.

30. MAKI, J. \& YANAGISAWA, T. - Studies on anthelmintic effects of flubendazole and mebendazole on the rat lungworm Angiostrongylus cantonensis in mice and rats. J. Parasit., 72: 512-516, 1986.

31. MAKI, J. \& YANAGISAWA, T. - Effect of flubendazole on the number of first-stage larvae of Angiostrongylus cantonensis released in the faeces of treated rats. J. Helminth., 64: 87-95, 1990.

32. MORERA, P. \& CÉSPEDES, R. Angiostrongilosis abdominal. Una nueva parasitosis humana. Acta méd. costarric., 14: 159-173, 1971.

33. MORERA, P. \& BONTEMPO, I. - Acción de algunos antihelmínticos sobre Angiostrongylus costaricensis. Rev. méd. Hosp. nac. Ninõs (Costa Rica), 20: 165174,1985

34. MORERA, P. - Angiostrongilíase abdominal. Um problema de Saúde Pública? Rev. Soc. bras. Med. trop., 21: 81-83, 1988.

35. PAUL, S.M.; SKOLNICK, P. \& ZATZ, M. - Avermectin B1a: an irreversible activator of the gamma-aminobutyric acid-benzodiazepine-chloride-ionophore receptor complex. Biochem. biophys. Res. Commun., 96: 632-638, 1980
36. SANO, M.; TERADA, M.; ISHII, A.; KINO, H. \& HAYASHI, M. - Studies on chemotherapy of parasitic helminths. (I). On the in vitro methods and paralyzing effects of avermectin B1a on Angiostrongylus cantonensis. Jap. J. Parasit., 30: 305 314, 1981.

37. SATO, Y.; SHIROMA, Y.; KIYUNA, S.; TOMA, H. \& KOBAYASHI, J. - Reduced effect of chemotherapy of strongyloidiasis in patients with concurrent HTLV-1 infection in Okinawa, Japan. Jap. J. trop. Med. Hyg., 20: 183-192, 1992.

38. TERADA, M.; DHAREJO, A.M.; ISHII, A.I. \& SANO, M. - Effects of milbemycin D on adult Angiostrongylus cantonensis in rats. Parasit. Res., 73: 375-380, 1987.

39. TERADA, M.; ISHII, A.I.; DHAREJO, A.M.; HAYASHI, M. \& SANO, M. - Studies on chemotherapy of parasitic helminths. (XXVIII). In vivo efficacy of milbemycin D against larval stages of Angiostrongylus cantonensis and Angiostrongylus costaricensis. Jap. J. Parasit., 36: 24-29, 1987.

40. TERADA, M.; ISHII, A.I.; KINO, H. \& SANO, M. - Studies on chemotherapy of parasitic helminths. (VII). Effects of various cholinergic agents on the motility of Angiostrongylus cantonensis. Jap. J. Pharmacol., 32: 633-642, 1982.

41. TERADA, M.; ISHII, A.I.; KINO, H. \& SANO, M. - Studies on chemotherapy of parasitic helminths. (XVIII). Mechanism of spastically paralyzing action of pyrantel in Angiostrongylus cantonensis. Experientia (Basel), 39: 1383-1385, 1983.

42. TERADA, M.; ISHII, A.I.; KINO, H. \& SANO, M. - Angiostrongylus cantonensis paralysis due to avermectin B1a and ivermectin. Exp. Parasit., 57: 149-157, 1984.

43. TERADA, M.; ISHII, A.; TUNGTRONGCHITR, A.; SANO, M. \& SHOMURA, T. Effects of PF1022A on developing larvae of Angiostrongylus costaricensis in mice, with special reference to route, dose and formulation. Jap. J. Parasit., 42: 199-210, 1993

44. TERADA, M.; KINO, H.; AKYOL, C.V. \& SANO, M. - Effects of mebendazole on Angiostrongylus costaricensis in mice, with special reference to the timing of treatment. Parasit. Res., 79: 441-443, 1993.

45. TERADA, M.; RODRIGUEZ, O.; DHAREJO, A.M.; ISHII, A.I. \& SANO, M. - Studies on chemotherapy of parasitic helminths. (XXVI). Comparative in vitro effects of various anthelmintics on the motility of Angiostrongylus costaricensis and Angiostrongylus cantonensis. Jap. J. Parasit., 35: 365-367, 1986.

46. TERADA, M. \& SANO, M. - Studies on chemotherapy of parasitic helminths. (XX). Neuropharmacological actions of Santonin on Angiostrongylus cantonensis and some other parasitic nematodes. Jap. J. Parasit., 34: 325-334, 1985

47. TERADA, M. \& SANO, M. - Effects of diethylcarbamazine on the motility of Angiostrongylus cantonensis and Dirofilaria immitis. Z. Parasitenk., 72: 375-385, 1986

48. TERADA, M. \& SANO, M. - Protective resistance against reinfection with Angiostrongylus costaricensis in mice treated with larvicidal anthelmintics afte primary infection. Jap. J. Parasit., 38: 344-352, 1989.

49. TERADA, M.; SANO, M.; ISHII, A.I. et al. - Studies on chemotherapy of parasitic helminths. (III). Effects of tuberostemonine from Stemona japonica on the motility of parasitic helminths and isolated host tissues. Nippon Yakurigaku Zasshi, 79: 93 $103,1982$.

50. TERADA, M.; SANO, M.; ISHII, A.I. et al. - Studies on chemotherapy of parasitic helminths. (IV). Effects of alkaloids from Sophora flavescens on the motility of parasitic helminths and isolated host tissues. Nippon Yakurigaku Zasshi, 79: 105 $111,1982$.

51. TERADA, M.; TUNGTRONGCHITR, A.; ISHIH, A.I. \& SANO, M. - Effects of mebendazole on abdominal angiostrongyliasis in mice after worm maturation: preliminary trials. Jap. J. Parasit., 41: 481-486, 1992.

52. THOMSON, A.W.; SMITH, S.W.G. \& CHAPPELL, L.H. - Cyclosporin A immune supressant and antiparasitic agent. Parasit. today, 2: 288-290, 1986. 
53. TUNGTRONGCHITR, A.; ISHIH, A.; TERADA, M. \& RADOMYOS, P. - Effects of sensitization on efficacy of mebendazole in mice infected with adult Angiostrongylus costaricensis. Trop. Med. Parasit., 44 : 322-326, 1993.

54. TUNGTRONGCHITR, A.; ISHII, A. \& TERADA, M. - Effects of mebendazole given intermittently or successively with various doses and intervals on murine Angiostrongyliasis costaricensis after worm maturation. Jap. J. Parasit., 42: 321330,1993
55. YOSHIMURA, K.; SUGAYA, H.; ISHIDA, K. et al. - The effect of cyclosporin A on Angiostrongylus cantonensis infection and eosinophilia in mice. Int. J. Parasit., 23: 997-1003, 1993.

Received: 23 May 2003

Accepted: 10 July 2003 